Brit. J. industr. Med., 1950, 7, 187

\title{
THE SIZE AND NATURE OF DUST PARTICLES FOUND IN LUNG TISSUE
}

\author{
BY \\ THOMAS BEDFORD and C. G. WARNER* \\ From the Medical Research Council Environmental Hygiene Research \\ Unit, London School of Hygiene and \\ Tropical Medicine
}

Ten years ago, when we were making a physical study of the dust hazard in south Wales anthracite mines as part of the Medical Research Council's early investigation of chronic pulmonary disease in coal miners, we had the opportunity of examining the dust particles on two slides containing sections of a lung of a man who had died from silicosis after many years' work as a shot-firer in one of the anthracite mines included in our study.

Of the two lung sections, one had been stained but was otherwise untreated, and the other had been incinerated and the soluble ash removed by treatment with hydrochloric acid. Passing reference to these observations has already been made (Bedford and Warner, 1943), but in view of the present renewed interest in particle size in relation to pneumoconiosis it seems desirable to record our data in greater detail.

\section{Method of Examination}

The sections were examined by a technique similar to that which we employed in the evaluation of samples of air-borne dust obtained with a thermal precipitator. . The microscope had a $2 \mathrm{~mm}$. oil-immersion apochromatic objective, N.A. 1.37, and a X15 eyepiece, giving an overall magnification of about 1,200. The source of illumination was a 100 c.p. " pointolite" lamp with a blue-green filter. With these optical arrangements dust particles of rather less than $\mathbf{0 . 2}$ micron diameter could be discerned in the nodules and reticulation areas as discrete entities. For the measurement of the size of the dust particles an eyepiece graticule of the type described by Patterson and Cawood (1936) was used. When particles were massed together in an aggregate efforts were made to count and measure the individual particles comprising the aggregate.

On the untreated section counts were made on three typical nodules and three typical reticulation areas. Each of these areas was indicated to us by our colleague Dr. D'Arcy Hart. Strips across each of these six areas were examined and in each area not less than 2,000 dust particles were measured. All particles greater than

* Now of the scientitic staff, National Coal Board.
0.4 micron in diameter were classified into the groups " coal" and " minerals other than coal".

Coal particles and any acid-soluble ash had been removed from the other slide by the processes of incineration and acid treatment, so it was expected that the size distributions of dust particles on this slide would agree more or less closely with those of the particles of minerals other than coal on the untreated section. On this treated slide Dr. D'Arcy Hart identified two areas -one a nodule and one a reticulation area-which had been examined on the untreated section, and particle-size distributions were ascertained for these areas.

We have referred to the classification of dust particles accordingly as they were of coal or of other minerals. Early in our study of air-borne dusts it had appeared to us that in the thermal precipitator records it was possible to discriminate between the coal and other particles, for what we interpreted to be anthracite particles, even down to very small sizes, were quite black, whereas those of other minerals were not black and had a glossy appearance. Tests were made of the validity of this discrimination, and the results justified the visual discrimination of coal from other minerals in the examination of our samples (Bedford and Warner, 1943). The distinction was therefore made as a matter of routine. Many particles less than 0.4 micron in size could be so classified, but in our routine examinations only particles of 0.4 micron or greater diameter were sub-divided into the two groups.

In our examination of the untreated lung section particles of coal and of other minerals were differentiated in the same way. All the dust seen in the incinerated section was "non-coal", and since about half the visible particles in that section were smaller than 0.4 micron it seemed desirable to attempt to estimate the numbers of small particles of minerals other than coal in the untreated section.

As we had observed with air-borne dust, in the dust deposits in the lung sections the ratio of the number of coal to the number of non-coal particles decreased rapidly with decreasing particle size. At sizes below about 2 microns the logarithm of the ratio of coal to non-coal particles diminished in proportion to the particle size. Thus, in the case of the one nodule which was examined on both the treated and the untreated sections, in the untreated section the coal to non-coal 
ratios at sizes of 0.4 to 0.8 microns, 0.8 to 1.2 microns, 1.2 to 1.6 microns, and 1.6 to 2.0 microns, were respectively $0 \cdot 85,2 \cdot 23,9 \cdot 47$, and $56 \cdot 0$. The logarithms of these ratios, plotted against the mean particle size fell very closely about a straight line, and it seemed likely that extrapolation for a short distance to smaller sizes was probably not a very hazardous procedure. The probable ratios of coal to non-coal particles were therefore estimated in that way, and the total counts of particles of under 0.2 microns and of 0.2 to 0.4 microns diameter were subdivided into coal and non-coal fractions on that basis.

\section{The Sizes of Dust Particles found in Lung Tissue}

Table 1 gives a comparison of the size distributions of dust particles measured in the selected $(a)$ nodule and $(b)$ reticulation area in the incinerated section with the size distributions of non-coal particles in the same areas of the untreated section.

Scrutiny of Table 1 shows that the percentage size distributions of the particles in the untreated section larger than 0.4 micron, and visually discriminated as minerals other than coal, are very similar to the

TABLE 1

COMPARISON OF SIZE DISTRIBUTIONS OF DUST PARTICLES IN INCINERATED AND ACID-TREATED SECTION AND OF NON-COAL PARTICLES IN UNTREATED SECTION

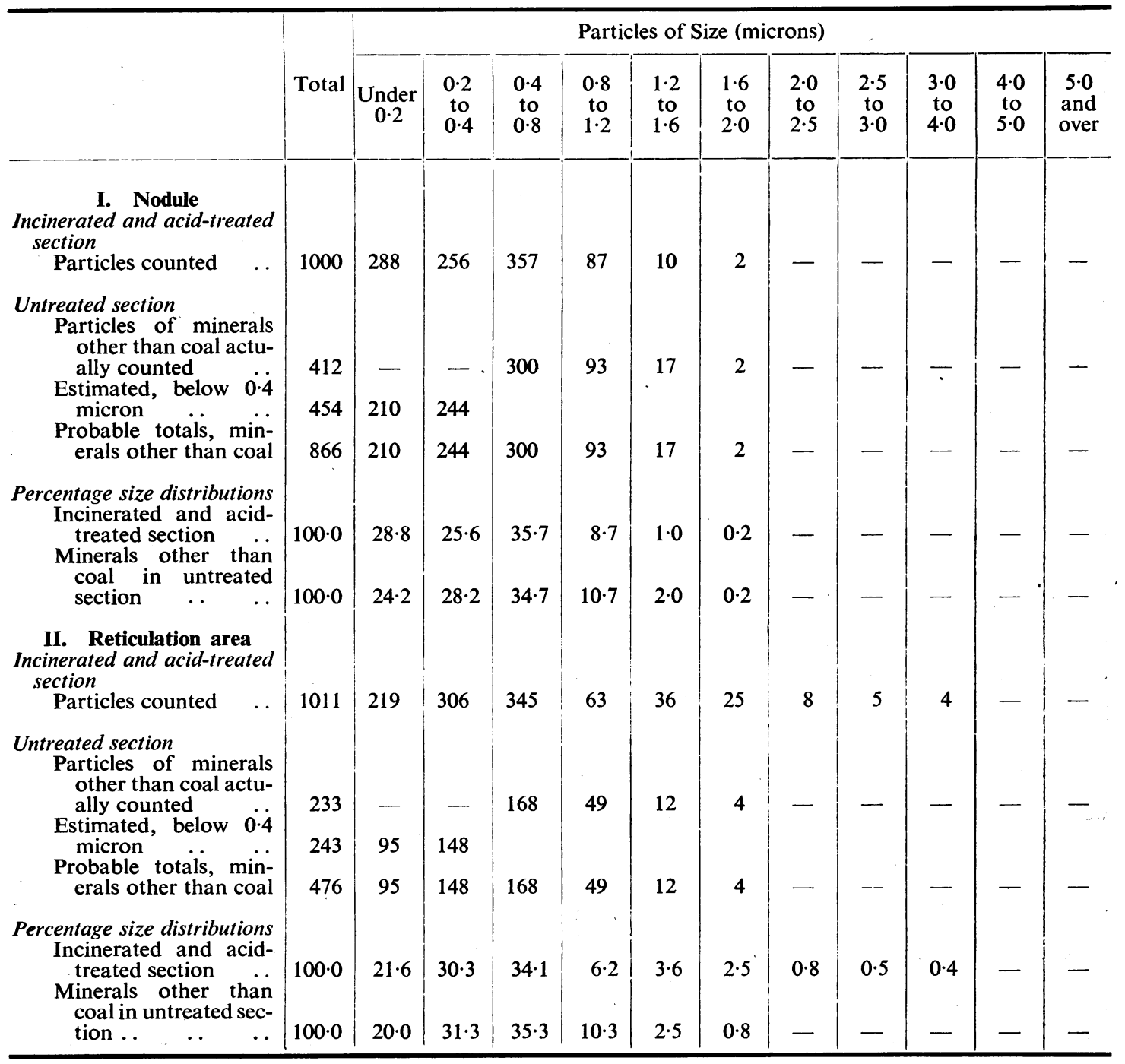


distributions of particles greater than 0.4 micron in the incinerated and acid-treated section. When, for the untreated section, the numbers of non-coal particles smaller than 0.4 micron are estimated by extrapolation, the proportions of these particles, in both the nodular and the reticulation areas, are very similar to those observed in the incinerated section. Hence the comparable percentage size distributions in Table 1 based on the numbers of particles of all sizes, counted or estimated, closely resemble each other.

In the untreated section, the size distributions of the dust particles measured in different nodules were found to be very similar, and the same was true of the size distributions for the different reticulation areas examined. Table 2 shows the size distributions of all the dust particles measured in the untreated section, without regard to the nature of the dust.
TABLE 3

TOTALS OF PARTICLES LARGER THAN 0.4 MICRON COUNTED IN 3 NODULES AND 3 RETICULATION AREAS OF UNTREATED SECTION OF LUNG

\begin{tabular}{l|c|c|c|c|c|c}
\hline & \multicolumn{2}{|c|}{ No. of Particles } & \multicolumn{2}{|c|}{ Percentage } \\
\hline & Coal & $\begin{array}{c}\text { Non- } \\
\text { coal }\end{array}$ & Total & Coal & $\begin{array}{c}\text { Non- } \\
\text { coal }\end{array}$ & Total \\
\hline $\begin{array}{c}\text { Nodules .. } \\
\begin{array}{c}\text { Reticulation } \\
\text { areas .. }\end{array}\end{array}$ & 3627 & 968 & 4595 & $78 \cdot 9$ & $21 \cdot 1$ & $100 \cdot 0$ \\
\hline
\end{tabular}

coal was $21 \cdot 1 \%$ in the nodules, and only $14.3 \%$ in the reticulation areas.

Table 4 gives the estimated numbers of particles of the two kinds of all sizes, the sub-division of the particles smaller than 0.4 micron having been carried

TABLE 2

SIZE DISTRIBUTIONS OF DUST PARTICLES (TOTAL DUST) IN UNTREATED SECTION

\begin{tabular}{|c|c|c|c|c|c|c|c|c|c|c|c|c|c|}
\hline & & \multirow[b]{2}{*}{ Total } & \multicolumn{11}{|c|}{ Particles of Size (microns) } \\
\hline & & & $\begin{array}{c}\text { Under } \\
0.2\end{array}$ & $\begin{array}{c}0 \cdot 2 \\
\text { to } \\
0 \cdot 4\end{array}$ & $\begin{array}{l}0.4 \\
\text { to } \\
0.8\end{array}$ & $\begin{array}{c}0 \cdot 8 \\
\text { to } \\
1 \cdot 2\end{array}$ & $\begin{array}{l}1 \cdot 2 \\
\text { to } \\
1 \cdot 6\end{array}$ & $\begin{array}{l}1 \cdot 6 \\
\text { to } \\
2 \cdot 0\end{array}$ & $\begin{array}{l}2 \cdot 0 \\
\text { to } \\
2 \cdot 5\end{array}$ & $\begin{array}{l}2 \cdot 5 \\
\text { to } \\
3 \cdot 0\end{array}$ & $\begin{array}{l}3 \cdot 0 \\
\text { to } \\
4 \cdot 0\end{array}$ & $\begin{array}{c}4 \cdot 0 \\
\text { to } \\
5 \cdot 0\end{array}$ & $\begin{array}{l}5 \cdot 0 \\
\text { and } \\
\text { over }\end{array}$ \\
\hline $\begin{array}{l}\text { Particles counted } \\
\text { Nodules ... .. } \\
\text { Reticulation areas }\end{array}$ & $\begin{array}{l}\cdots \\
\cdots\end{array}$ & $\begin{array}{l}6059 \\
6112\end{array}$ & $\begin{array}{l}565 \\
370\end{array}$ & $\begin{array}{l}899 \\
728\end{array}$ & $\begin{array}{l}1553 \\
1476\end{array}$ & $\begin{array}{r}945 \\
1124\end{array}$ & $\begin{array}{l}568 \\
642\end{array}$ & $\begin{array}{l}516 \\
578\end{array}$ & $\begin{array}{l}374 \\
446\end{array}$ & $\begin{array}{l}261 \\
258\end{array}$ & $\begin{array}{l}275 \\
312\end{array}$ & $\begin{array}{r}86 \\
153\end{array}$ & $\begin{array}{l}17 \\
25\end{array}$ \\
\hline $\begin{array}{c}\text { Percentage size distril } \\
\text { Nodules .. . } \\
\text { Reticulation areas }\end{array}$ & $\begin{array}{c}\text { ions } \\
\cdots \\
\cdots\end{array}$ & $\begin{array}{l}100 \cdot 0 \\
100 \cdot 0\end{array}$ & $\begin{array}{l}9 \cdot 3 \\
6 \cdot 1\end{array}$ & $\begin{array}{l}14 \cdot 8 \\
11.9\end{array}$ & $\begin{array}{l}25 \cdot 7 \\
24 \cdot 1\end{array}$ & $\begin{array}{l}15 \cdot 6 \\
18 \cdot 4\end{array}$ & $\begin{array}{r}9.4 \\
10.6\end{array}$ & $\begin{array}{l}8 \cdot 5 \\
9 \cdot 4\end{array}$ & $\begin{array}{l}6 \cdot 2 \\
7 \cdot 3\end{array}$ & $\begin{array}{l}4 \cdot 3 \\
4 \cdot 2\end{array}$ & $\begin{array}{l}4 \cdot 5 \\
5 \cdot 1\end{array}$ & $\begin{array}{l}1 \cdot 4 \\
2 \cdot 5\end{array}$ & $\begin{array}{l}0 \cdot 3 \\
0 \cdot 4\end{array}$ \\
\hline
\end{tabular}

The distributions for nodules and for reticulation areas are very similar, but the nodules contained the slightly larger proportion of very small particles. It will be shown later that differences in the proportions of coal and other particles account for this difference in the size distributions of the whole dust.

Of all the particles measured, 0.3 or $0.4 \%$ were larger than 5 microns. If any of these were aggregations of smaller particles we failed to discern it. Seventeen such particles were measured in nodules, and of these 15 were 6 microns in diameter, and the remaining two were 8 microns in size. Of the 25 particles larger than 5 microns measured in reticulation areas, 22 were 6 microns and three were 8 microns in diameter.

\section{The Nature of the Dust}

The numbers of particles of coal and of minerals other than coal discriminated visually down to a diameter of 0.4 micron are shown in. Table 3 .

The proportion of particles of minerals other than out by the extrapolation method previously described.

Here, again, the proportion of non-coal particles in the nodules is about one and a half times as large as in the reticulation areas, but the actual percentages of non-coal particles are distinctly higher.

The size distributions of particles of coal and of other minerals are given in Table 5 . The subdivision

\section{TABLE 4}

TOTALS OF PARTICLES OF ALL SIZES COUNTED AND ESTIMATED IN NODULES AND RETICULATION AREAS OF UNTREATED SECTION

\begin{tabular}{c|c|c|c|c|c|c}
\hline & \multicolumn{2}{|c|}{ No. of Particles } & \multicolumn{2}{|c|}{ Percentage } \\
\cline { 2 - 7 } & Coal & $\begin{array}{c}\text { Non- } \\
\text { coal }\end{array}$ & Total & Coal & $\begin{array}{c}\text { Non- } \\
\text { coal }\end{array}$ & Total \\
\hline $\begin{array}{c}\text { Nodules .. } \\
\begin{array}{c}\text { Reticulation } \\
\text { areas .. }\end{array}\end{array}$ & 4004 & 2055 & 6059 & $66 \cdot 1$ & $33 \cdot 9$ & $100 \cdot 0$ \\
\hline
\end{tabular}


TABLE 5

SIZE DISTRIBUTIONS OF PARTICLES OF COAL AND OF OTHER MINERALS* FOUND IN NODULES AND RETICULATION AREAS IN UNTREATED SECTION

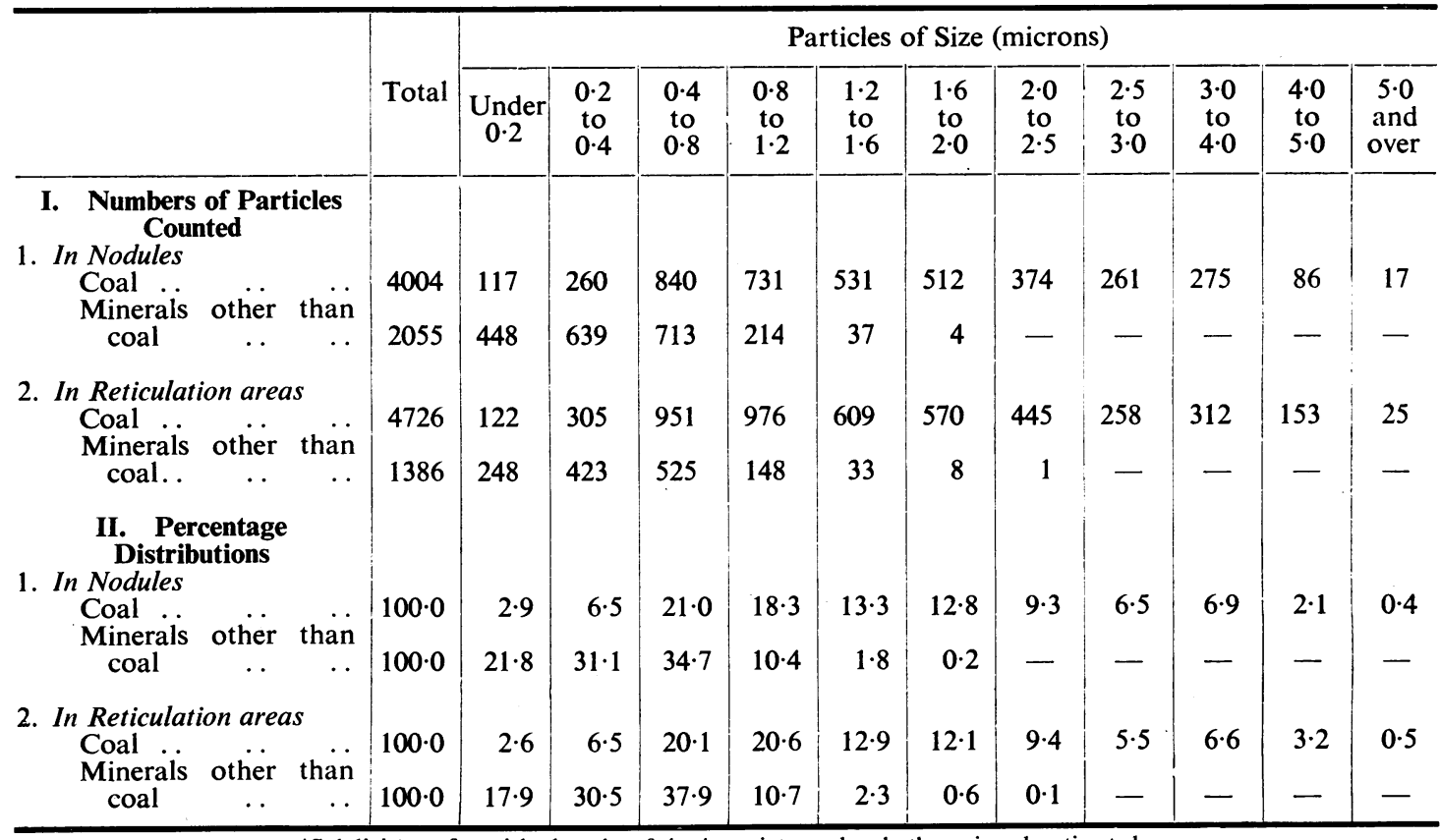

*Subdivision of particles less than 0.4 micron into coal and other minerals estimated.

of particles below $0 \cdot 4$ micron in size into coal and other minerals has been estimated.

The percentage size distributions of the coal particles found in nodules and in reticulation areas are practically identical, and the same applies to particles of minerals other than coal. As in the dust clouds in mine air, the larger particles are of coal, while it is estimated that of the non-coal particles 86 or $87 \%$ were less than 0.8 micron in diameter.

The difference between the size distributions of the whole dust found in nodules and in reticulation areas, which are noted in Table 2, are due to the different proportions of the two fractions of the dust present. The dust in the reticulation areas contains relatively more coal and less minerals other than coal than is found in nodules. It is not for us to discuss how this has arisen, but since the size distributions of the two fractions of dust are the same at the two sites there appears to have been no discrimination as to the size of particles conveyed.

Pathological Significance of Particle Size

As a solid material is disintegrated into smaller and yet smaller particles, the surface area of a given weight of the solid is much increased, so that those properties which depend upon the activity of the surface molecules are greatly enhanced. Very large dust particles are probably, therefore, of little pathological significance. There is, however, some difference of opinion as to the maximum particle size which can be considered to be of pathological importance. Gardner (1939) reported :

"We have injected a series of doses of silica particles of different sizes having comparable surface areas. Regardless of the total surface area the silica-significant reaction only occurs when the particles are 3 microns or less in diameter".

It seems to be fairly generally accepted by American workers that in estimating the dust hazard particles larger than about 3 microns can be ignored, and Sayers and Jones (1938) mention that the majority of particles found in the lung are 1 to 3 microns in size.

In our examination of lung sections we found dust particles as large as $\mathbf{8}$ microns, but they were of coal. In the non-coal fraction of the dust in our specimens (which fraction presumably contains all or virtually all of the siliceous material) no particles larger than 4 microns were noted, but the number of particles of minerals other than coal larger than 4 microns present in the air of an anthracite mine is small. Gardner (1939) remarks that particles as large as 10 microns are found in human lungs.

We made many observations of air-borne dust at the colliery where the man from whom our specimens were taken had worked for many years. 


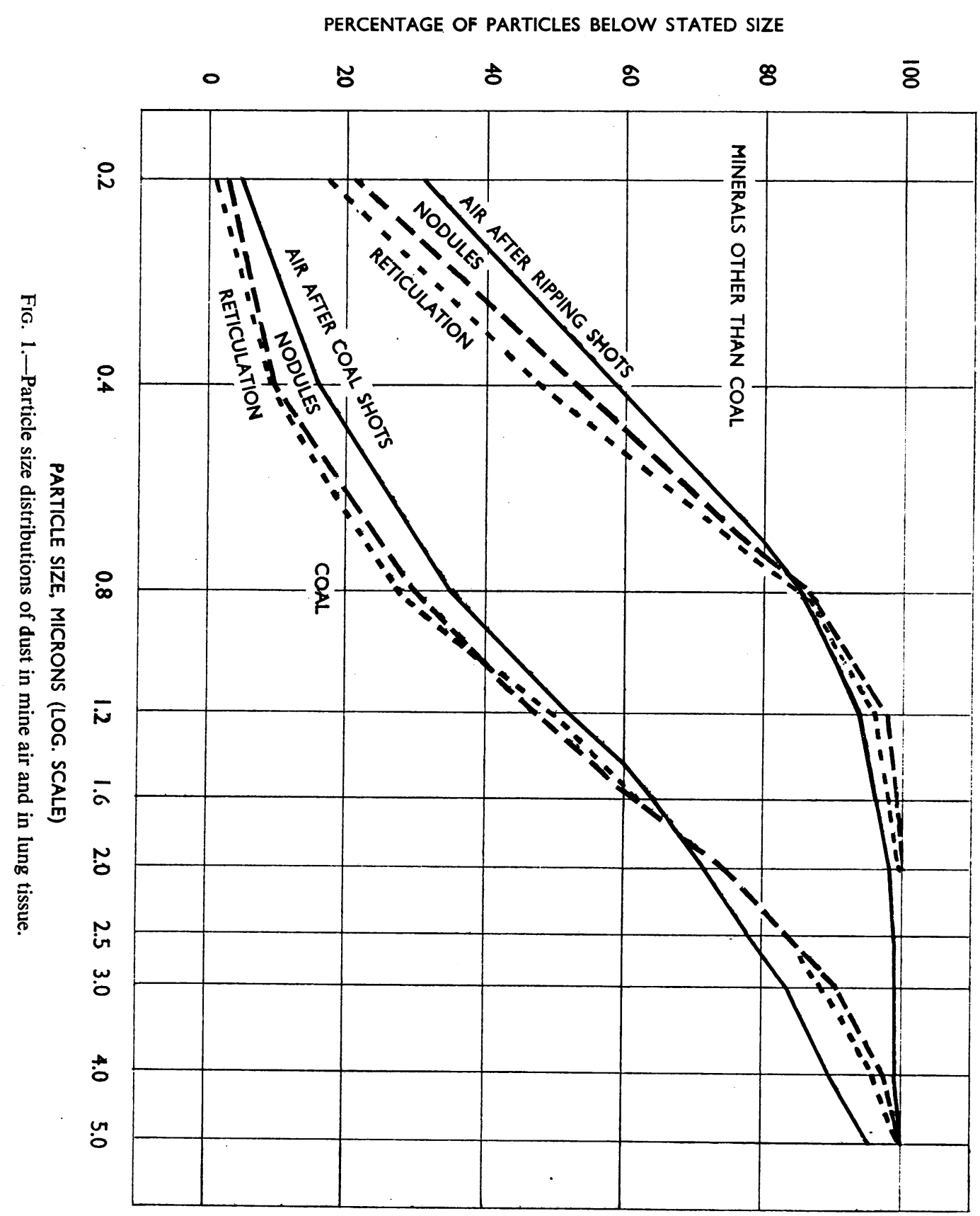


The size distributions of non-coal particles found in the lung sections were rather similar to the distributions of non-coal particles in the air-borne dust after ripping shots had been fired in stall roads, and the coal particles found in the lung tissue had size distributions not unlike the distribution of coal-dust particles after shots had been fired in coal.

In Table 6 the particle size distribution of the dust of minerals other than coal found in the air after ripping shots had been fired is compared with the distributions of such dust found in lung sections ; and, similarly, the size distribution of air-borne coal dust at the coal-face after shots had been fired in the coal is compared with the distributions of and $23 \%$ of the 5 -micron particles inhaled are retained in the alveoli.

From the curves given by Brown and his colleagues we have computed the limits of the percentage size distributions of the inhaled dusts that might have been expected to give rise to deposits with size distributions such as we found in reticulation areas. In these calculations it has been assumed that our non-coal particles had a density equal to that of china clay, and that the density of our coal particles was one-half that of china clay. The computed size distributions are shown in broken lines in Fig. 2, for both the coal and the non-coal fractions of the dust. Fig. 2 also shows the size

TABLE 6

COMPARISON OF PARTICLE SIZE DISTRIBUTIONS OF DUST IN MINE AIR AND IN LUNG TISSUE

\begin{tabular}{|c|c|c|c|c|c|c|c|c|c|c|c|}
\hline \multirow{2}{*}{ Dust } & & \multicolumn{10}{|c|}{ Percentage of Particles of Diameter Less than (microns) } \\
\hline & & 0.2 & 0.4 & 0.8 & $1 \cdot 2$ & 1.6 & $2 \cdot 0$ & $2 \cdot 5$ & 3.0 & 4.0 & 5.0 \\
\hline $\begin{array}{l}\text { Minerals other than coal } \\
\text { In colliery air after ripping shots } \\
\text { In lung tissue (nodules) ... } \\
,, \quad,, \quad \text { (reticulation areas) }\end{array}$ & $\begin{array}{l}\cdots \\
\cdots \\
\cdots\end{array}$ & $\begin{array}{l}31 \cdot 2 \\
21 \cdot 8 \\
17 \cdot 9\end{array}$ & $\begin{array}{l}59 \cdot 5 \\
52 \cdot 9 \\
48 \cdot 4\end{array}$ & $\begin{array}{l}85 \cdot 9 \\
87 \cdot 6 \\
86 \cdot 3\end{array}$ & $\begin{array}{l}94 \cdot 9 \\
98 \cdot 0 \\
97 \cdot 0\end{array}$ & $\begin{array}{l}96 \cdot 5 \\
99 \cdot 8 \\
99 \cdot 3\end{array}$ & $\begin{array}{r}98 \cdot 4 \\
100 \cdot 0 \\
99 \cdot 9\end{array}$ & $\frac{99 \cdot 0}{100 \cdot 0}$ & $\begin{array}{c}99 \cdot 0 \\
-\end{array}$ & $\frac{99 \cdot 0}{-}$ & $\begin{array}{c}100 \cdot 0 \\
-\end{array}$ \\
\hline $\begin{array}{l}\text { Coal } \\
\text { In colliery air after shots in coal } \\
\text { In lung tissue (nodules) .. } \\
,,, \quad,, \quad \text { (reticulation areas) }\end{array}$ & $\begin{array}{l}\cdots \\
\cdots \\
\cdots\end{array}$ & $\begin{array}{l}4 \cdot 7 \\
2 \cdot 9 \\
2 \cdot 6\end{array}$ & $\begin{array}{r}16 \cdot 6 \\
9 \cdot 4 \\
9 \cdot 1\end{array}$ & $\begin{array}{l}35 \cdot 9 \\
30 \cdot 4 \\
29 \cdot 2\end{array}$ & $\begin{array}{l}52 \cdot 9 \\
48 \cdot 7 \\
49 \cdot 8\end{array}$ & $\begin{array}{l}64 \cdot 7 \\
62 \cdot 0 \\
62 \cdot 7\end{array}$ & $\begin{array}{l}72 \cdot 2 \\
74 \cdot 8 \\
74 \cdot 8\end{array}$ & $\begin{array}{l}78 \cdot 1 \\
84 \cdot 1 \\
84 \cdot 2\end{array}$ & $\begin{array}{l}83.9 \\
90 \cdot 6 \\
89.7\end{array}$ & $\begin{array}{l}90 \cdot 1 \\
97 \cdot 5 \\
96 \cdot 3\end{array}$ & $\begin{array}{l}94 \cdot 8 \\
99 \cdot 6 \\
99 \cdot 5\end{array}$ \\
\hline
\end{tabular}

coal dust in the lung tissue. The classification of the particles in the lowest two size-groups as coal or as other minerals has been done by the method described earlier. The data are also shown graphically in Fig. 1.

The size distributions of the dust in the lung sections are similar in type to those of the air-borne dust after shot-firing, i.e., at the times when the highest dust concentrations were likely to have been encountered. In the lung sections the fraction of the dust containing siliceous material contained no large particles, but large particles of minerals other than coal were exceedingly rare in the airborne dust. In the lung sections the proportions of finer particles in both the coal and the non-coal fractions of the dust were lower than in the airborne dust, and this is in general accord with the known facts concerning the retention of fine dust in the lungs.

In a recent paper, Brown, Cook, Ney, and Hatch (1950) report the results of a study of the influence of particle size upon the retention of particulate matter (china clay) in the human lung, and they give the calculated upper and lower limits of alveolar deposition of particles of various sizes. Alveolar deposition is at a maximum (about 55\%) for particles of 1 micron diameter, while between 8 distributions of non-coal particles observed in the mine air after ripping shots had been fired; and the size distributions of coal particles observed $(a)$ after shots had been fired in coal, and $(b)$ in the air of gate roads under ordinary travelling conditions when no shots had recently been fired. The distribution of non-coal particles observed in the mine air after ripping shots had been fired, i.e., when the shot-firer probably is most severely exposed to non-coal dust, is remarkably similar to the computed distribution. The computed size distributions for the coal fraction of the dust are very similar to the observed distributions of air-borne coal particles under normal conditions in gate roads, where the shot-firer spends much of his time walking from one working place to another, and at the coal face after shots had been fired in coal. If these two observed distributions were averaged the resultant mean distribution would be entirely within the calculated limits. Belt and Ferris (1942) remarked that the collier's lung is in a very real sense his occupational log book, and our data appear to give support to that statement.

There is one other point that seems worthy of mention. During a discussion of our data with colleagues it was suggested that the similarity between the sizes of particles in nodules and in reticulation areas seemed to indicate that no notable 


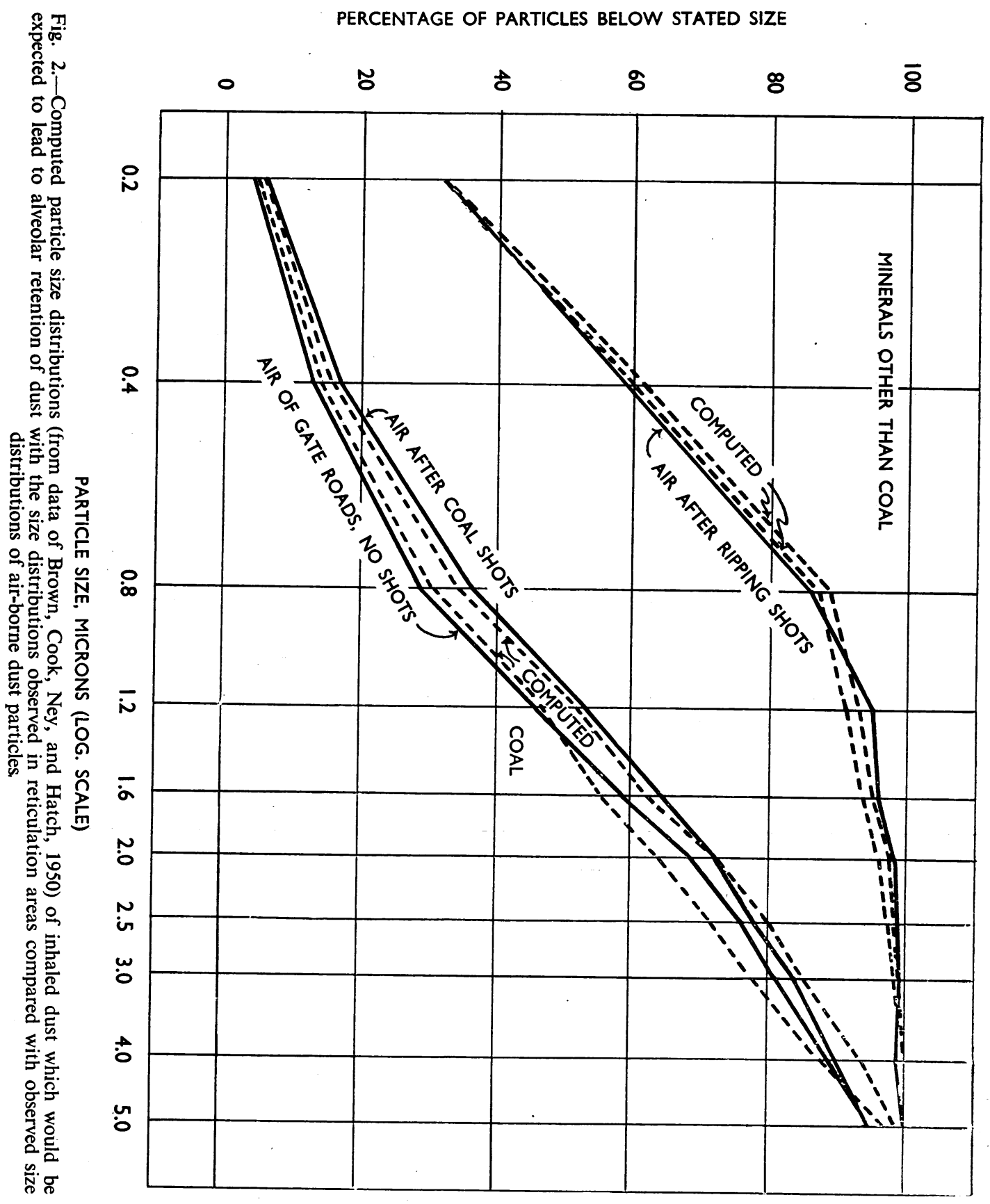


reduction in size occurred after particles had resided in nodules for a period of years, and that the question might therefore arise whether the nodule in the coal miner is a foreign body reaction rather than a tissue reaction aroused by the solution of mineral matter. We doubted whether such an interpretation could be attached to our data, and as a rough test we estimated from the percentage size distribution of the non-coal particles found in reticulation areas (Table 5) what would be the probable size distribution of the remaining dust if some solution occurred. Although solubility is a function of particle size we assumed that from all the particles the outer layer would be dissolved for a uniform thickness of 0.025 micron, 0.05 micron, and 0.10 micron ; that is, we assumed reductions of the diameters of the particles of $0.05,0.1$, and 0.2 micron.

The results of these calculations are shown in Table 7. With each degree of solution assumed some of the smallest particles would be dissolved
Size distributions are given separately for particles of coal and of minerals other than coal.

Particles were examined $(a)$ in nodules, and (b) in reticulation areas. Of all the particles measured 0.3 to $0.4 \%$ were larger than 5 microns, and particles as large as 8 microns were found in both nodules and reticulation areas. As in the dust clouds in mine air, the larger particles were of coal. Of the non-coal particles 86 or $87 \%$ were less than 0.8 micron in diameter.

The size distributions of the dust in the lung sections were similar in type to those of the air-borne dust, after shot-firing, at the colliery where the man had worked, although the proportion of very small particles was somewhat smaller in the lung sections than in the air-borne dust. It is shown that when allowance is made for the effects of particle size on alveolar retention, the observed size distributions of the air-borne dust are very close to what would be expected to account for the size distributions of the dust particles found in the lung tissue.

TABLE 7

PERCENTAGE SIZE DISTRIBUTIONS OF PARTICLES OF MINERALS OTHER THAN COAL SHOWING ESTIMATED EFFECTS OF REDUCTION OF SIZE BY SOLUTION OF OUTER LAYERS OF PARTICLES

\begin{tabular}{|c|c|c|c|c|c|c|c|c|c|c|}
\hline & & & & & & \multicolumn{5}{|c|}{$\begin{array}{c}\text { Percentage of Particles of Minerals other than Coal within Given } \\
\text { Range of Particle Size }\end{array}$} \\
\hline \multirow{2}{*}{\multicolumn{6}{|c|}{ Range of Particle Size }} & \multirow{2}{*}{$\begin{array}{c}\text { Observed in } \\
\text { Reticulation } \\
\text { Areas }\end{array}$} & \multicolumn{3}{|c|}{$\begin{array}{l}\text { Estimated after Assumed Loss by } \\
\text { Solution of a Layer of Thickness of }\end{array}$} & \multirow{2}{*}{$\begin{array}{l}\text { Observed in } \\
\text { Nodules }\end{array}$} \\
\hline & & & & & & & 0.025 micron & 0.05 micron & 0.10 micron & \\
\hline $\begin{array}{c}\text { Below } \\
\text {," } \\
\text { ", } \\
\text {," }\end{array}$ & $\begin{array}{l}0.4 \\
0.8 \\
1.2 \\
1.6 \\
2.0 \\
2.5\end{array}$ & $\begin{array}{l}\text { icrons } \\
\text {," } \\
\text { ", } \\
\text { ", }\end{array}$ & $\begin{array}{l}\ldots \\
\cdots \\
\cdots \\
\cdots \\
\cdots\end{array}$ & $\begin{array}{l}\cdots \\
\cdots \\
\cdots \\
\cdots \\
\cdots\end{array}$ & $\begin{array}{l}\ldots \\
\ldots \\
\ldots \\
\ldots \\
\ldots \\
\ldots\end{array}$ & $\begin{array}{r}48 \cdot 4 \\
86.3 \\
97.0 \\
99 \cdot 3 \\
99.9 \\
100.0\end{array}$ & $\begin{array}{r}48 \cdot 1 \\
85 \cdot 7 \\
96 \cdot 8 \\
99 \cdot 3 \\
99 \cdot 9 \\
100 \cdot 0\end{array}$ & $\begin{array}{r}48 \cdot 1 \\
86 \cdot 5 \\
96.9 \\
99 \cdot 4 \\
100 \cdot 0 \\
100 \cdot 0\end{array}$ & $\begin{array}{r}51 \cdot 3 \\
88 \cdot 2 \\
97 \cdot 4 \\
99 \cdot 6 \\
100 \cdot 0 \\
100 \cdot 0\end{array}$ & $\begin{array}{r}52.9 \\
87.6 \\
98.0 \\
99.8 \\
100.0 \\
100.0\end{array}$ \\
\hline \multicolumn{6}{|c|}{$\begin{array}{l}\text { Percentage reduction of volume (or } \\
\text { weight) of dust } \ldots\end{array}$} & - & 16 & 33 & 53 & - \\
\hline
\end{tabular}

completely or would become too small to be seen by our microscope technique, and allowance has been made for that effect. With solution of a layer 0.1 micron in thickness, we estimate that the weight of the dust would be reduced by about one-half. Yet in spite of this the computed size distributions are virtually the same as that of the original dust in the reticulation areas. Thus, our data should not be taken to indicate that no solution occurs after the dust particles are deposited in the lung tissue.

\section{Summary}

The paper gives detailed size distributions of dust particles found in specimens of lung tissue from a shot-firer who had died from silicosis after many years' work in an anthracite mine.
In nodules and in reticulation areas the particle size distributions were very similar. Rough calculations of the effects of partial solution of the dust on particle size distribution suggest that the similarity of the size distributions should not be taken to indicate that no solution occurs after particles are deposited in lung tissue.

\section{REFERENCES}

Bedford, T., and Warner, C. G. (1943). Spec. Rep. Ser. Med. Res. Coun., Lond., No. 244, Part B.

Belt, T. H., and Ferris, A. A. (1942). Ibid. No. 243, Part C.

Brown, J. H., Cook, K. M., Ney, F. G., and Hatch, T. (1950). Amer. J. Publ. Hlth, 40,450 .

Gardner, Publ. Hlth., 40, 450. Foundation of America, p. 41 .

Patterson, H. S., and Cawood, W. (1936). Trans. Faraday Soc., 32, 1084.

Sayers, R. R., and Jones, R. R. (1938). Publ. Hlth. Rep., Wash., 53,1453 . 